\title{
Electrochemical Study of Isatin-3-(methyenel)- hydrazone Schiff Base on Carbon Paste Electrode
}

\author{
ARTI SAXENA*, RATNESH DAS and SHWETA SAXENA \\ Department of Chemistry, Dr. Hari Singh Gour Central University, Sagar M.P, India \\ artisaxena21@rediffmail.com
}

Received 19 June 2015 / Accepted 26 June 2015

\begin{abstract}
This work explains the electrochemical behavior of isatin-3-(methyenel)hydrazone that is formed by the reaction of isatin-3hydrazone and formaldehyde. The electrochemical behavior of synthesized compound was investigated in phosphate buffer, $\mathrm{LiCl}$ as a supporting electrolyte and at carbon paste electrode by cyclic voltammetry. In this study we find oxidizing product of synthesized Schiff base strongly adsorbed on the carbon paste electrode and show quasi reversible nature at initial scan rate.
\end{abstract}

Keywords: Isatin-3-(methyenel)-hydrazone Schiff base, Redox behaviour, Carbon paste electrode

\section{Introduction}

The indole is strong pharmacodynamic moiety and possesses important biological properties such as anti-inflammatory, anti bacterial, anti convulsant, antioxidant properties ${ }^{1-3}$. Indole derivatives such as melatonin and its related structure indole-3-propionic derivatives behave as important class of anti oxidant compound and potentially useful against Alzheimer disease $^{4-9}$. Indole or its related compound like isatin etc. are well known electro active compound that are easily reduce and oxidize at carbon based electrode like glassy carbon electrode. Among the indole, indole-2, 3 dione is a excellent heterocyclic compound present in human, as a metabolic derivatives of adrenaline ${ }^{10}$ and mammalian tissue and body fluid $^{11,12}$. Isatin also work as modulator of different kind of biochemical processes like inhibitor of monoamine oxidase (MAO) and later on identified as a selective inhibitor of monoamine oxidase $\mathrm{B}^{11,13}$. Isatin is a synthetically very important moiety that can be use for the preparation of different isatin derivatives, which possess broad clinical and pharmacological application ${ }^{14-16}$. Isatin hydrazone derivatives are important group of compound called hydrazones. Because of azometin proton these play an important role in drug discovery ${ }^{17,18}$ and it was revealed from literature that they have anti tumoral, anti TB, anti inflammatory, antiplatelet, analgesic, antimicrobial, anti convulsant activity ${ }^{19}$. In present time indole and its related compound have gained lot of attention due to its wide importance in synthetic and analytical purposes. Isatin attract organic chemist attention due presence of two carbonyl group. Electrochemical behaviour of isatin and analogous compound has been recorded using mercury electrode ${ }^{20-23}$. 
Further study has shown that isatin and its derivatives possess broad range of application in synthetic, biological and clinical activity. It has shown oxidation and reduction at glassy carbon electrode. The oxidation of isatin was found to be $\mathrm{pH}$ dependent and the reduction of isatin was irreversible and show two consecutive electron transfer reaction, this study done by $\mathrm{CV}^{24}$. The electrochemical determination of isatin ${ }^{25}$ and other nitrogen containing heterocycles taking variety of electrode systems ${ }^{26,27}$ attain a distinguished position in recent years. 3-Arylimino derivatives (Schiff bases) obtained by the condensation of aromatic amines with isatin, are powerful antibacterial, anticonvulsant, antiviral and anti fungal agent ${ }^{28-30}$. Copper(II) complex of isatin Schiff base ligand are potential antitumor agent ${ }^{31}$. Recent achievement indicate isatin interact with wide range of monoamine in the biological systems ${ }^{32}$. Investigation of electrochemical behavior of biologically important compound by electrochemical technique like cyclic voltamtery, DPV, SWV have efficiency for giving valuable information like redox properties of biologically important compound, its reduction or oxidation potential and stability in the body fluid etc. for this purpose today, voltammetric technique have been successfully used due to its high sensitivity ${ }^{33-36}$. In this paper we synthesized isatin 3 hydrazone Schiff base and done its electrochemical study using carbon pest electrode and phosphate buffer.

\section{Experimental}

Cyclic voltammetry was performed using a Metrohm 797 V.A. Computrace (Swiss made). The working electrode used in this study was carbon pest electrode $(\mathrm{d}=0.2 \mathrm{~cm})$ which prepared by mixing graphite powder with paraffin wax in 3:7 ratio, then it was sonicated for $1 \mathrm{~min}$ in an ultrasound bath and again rinsed with water. Platinum wire used as a counter electrode and $\mathrm{Ag} / \mathrm{AgCl}(3 \mathrm{M} \mathrm{KCl})$ taking as reference electrode. All three electrodes taking in one compartment chamber, in which magnetic stirrer equipped. The electrochemical oxidation was performed under constant potential condition. The potential of working electrode measure against $\mathrm{Ag} / \mathrm{AgCl}$ reference electrode. All study was carried out at $25 \pm 2{ }^{\circ} \mathrm{C}$ temperature. Chemicals purchased from Sigma-Aldrich, Himedia and used without purification. Melting point was determined by using open capillary tube melting point apparatus. The IR spectra were recorded on a FTIR Shimadzu-8400S spectrometer using $\mathrm{KBr}$ pellets. The ${ }^{1} \mathrm{H}$ NMR and ${ }^{13} \mathrm{C}$ NMR spectra were recorded on Varian 300 spectrometer taking TMS as standard and DMSO as a solvent. Sonication was done with the help of frontline sonicator (with a frequency of $22 \mathrm{KHz}$ with a normal power of $225 \mathrm{~W}$ ). The $\mathrm{pH}$ measurement was carried out by $\mu \mathrm{pH}$ system 361 digital $\mathrm{pH}$ meter.

\section{Sample preparation}

For cyclic voltammetry $(\mathrm{CV})$ solutions were prepared by mixing $7.0 \mathrm{~mL}$ of $0.01 \mathrm{M}$ stock solution and $1.0 \mathrm{~mL}$ of $0.1 \mathrm{M} \mathrm{LiCl}$ (as supporting electrolyte) and $2.0 \mathrm{~mL}$ of $0.2 \mathrm{M}$ appropriate (phosphate) buffer. Nitrogen gas was passed in the solution for $\sim 15$ minutes and thereafter, a blanket of nitrogen gas was maintained throughout the experiment. During the experiment solution was subjected to controlled potential electrolysis.

\section{Synthesis of Schiff base}

Isatin-3-hydrazone and formaldehyde were dissolved in $30 \mathrm{~mL}$ DMF in presence of protonation reagent i.e. glacial acetic acid $(.01 \mathrm{~mL})$ was kept at $60{ }^{\circ} \mathrm{C}$ on water bath for $30 \mathrm{~min}$ with continuing stirring. The purity of compound was checked by TLC using Merck pre-coated gel GF aluminum plates. Benzene: chloroform: methanol taking as a mobile phase. The reaction mixture was poured into water $(300 \mathrm{~mL})$ and recrystalization done by ethanol as a solvent. 


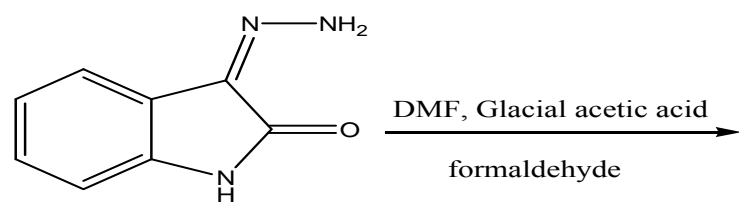

Isatin 3 hydrazone

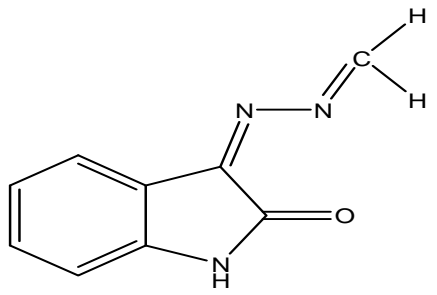

Isatin-3(methhyenel) hydrazone schiff base

\section{Scheme 1.}

\section{Characteristics of product}

Isatin-3-(methyenel)-hydrazone: FTIR $(\mathrm{KBr})\left(\mathrm{V}_{\max } \mathrm{cm}^{-1}\right): 1340(\mathrm{C}-\mathrm{N}), 1668(\mathrm{C}=\mathrm{O}), 1583$ $(\mathrm{C}=\mathrm{C}), 3450(\mathrm{~N}-\mathrm{H}), 1222(\mathrm{C}-\mathrm{O}), 3305(\mathrm{~N}-\mathrm{N}), 1450(\mathrm{H}-\mathrm{C}-\mathrm{H}),{ }^{1} \mathrm{H}$ NMR (300 MHz, DMSO, TMS, $\delta$ ppm): $7\left(\mathrm{~m}, 8 \mathrm{H}, \mathrm{H}_{\mathrm{Ar}}\right), 3.8\left(\mathrm{~s}, 2 \mathrm{H}, \mathrm{CH}_{2}\right), 10.7\left(\mathrm{~s}, \mathrm{H}_{\text {enolic }}\right), 8.3(\mathrm{~d}, 1 \mathrm{H}, \mathrm{NH}) ;{ }^{13} \mathrm{C} \mathrm{NMR}$ $\left(400 \mathrm{MH}_{\mathrm{Z}}, \mathrm{CDCl}_{3}, \delta\right.$ ppm) $\delta_{\mathrm{c}}: 162,131,125,138,165$.

\section{Results and Discussion}

\section{Cyclic voltammetric studies}

This paper explains the electrochemical behaviour of isatin-3-hydrazone Schiff base at a carbon paste electrode and this experiment were carried out in $0.2 \mathrm{M}$ phosphate buffer and $0.1 \mathrm{M} \mathrm{LiCl}$ as supporting electrolyte. Isatin -3-(methyenel)hydrazone show voltammograms at $\mathrm{pH}$ 6.8. During the voltammetric measurement a constant flux of $\mathrm{N}_{2}$ was kept over the solution surface in order to avoid the diffusion of atmospheric oxygen into the solution. In this study purging time is $15 \mathrm{~s}$, deposition time is $50 \mathrm{~s}$ and deposition potential is $-0.9 \mathrm{~V}$. Several peaks were observed. Study of effect of scan rate is made in order to find out the mechanism and the feasibility of the reaction.

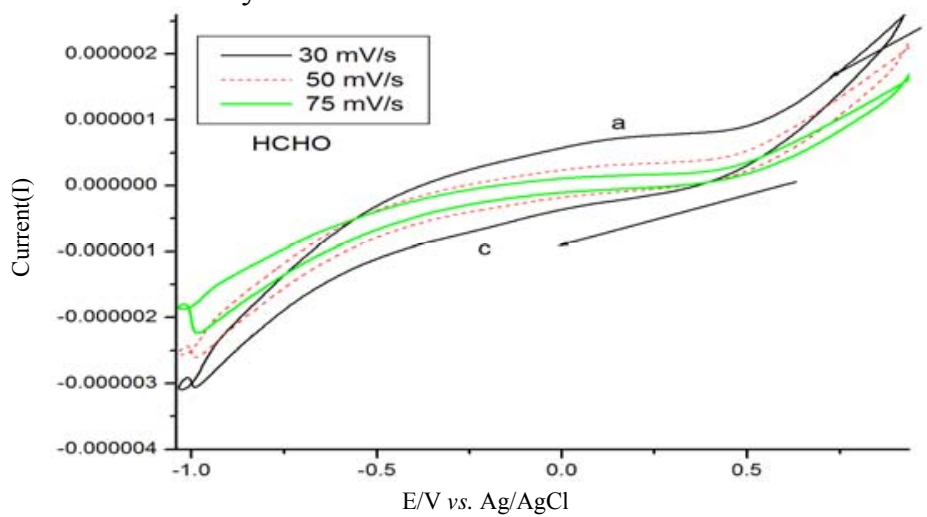

Figure 1. Cyclic voltamogram of isatin -3(methyenel)-hydrazone at carbon paste electrode in phosphate buffer solution ( $\mathrm{pH} 6.8, \mathrm{c} .01 \mathrm{M}$ ) scan rate $30-50 \mathrm{mV} / \mathrm{s}$, temp $=25 \pm 2{ }^{\circ} \mathrm{C}$

Representative cyclic voltamogram of Schiff base $(0.01 \mathrm{M})$ in phosphate buffer $(\mathrm{pH} 6.8$, c $.2 \mathrm{M}$ ) at carbon paste electrode. Ongoing scan in the positive direction, one oxidation or anodic peak appear, when scanning is reverse in the negative direction we get one reduction or cathodic peak at scan rate $30 \mathrm{mV} / \mathrm{s}$. anodic and cathodic peak potential for such Schiff 
base are +0.164 and $-0.232 \mathrm{~V}$ vs. $\mathrm{Ag} / \mathrm{AgCl}$ reference electrode respectively at scan rate $30 \mathrm{mV} / \mathrm{s}$ this can be seen in Figure 1 and The $\mathrm{E}^{0}$ value is $-0.03 \mathrm{~V}$. due to the adsorption of this oxidize compound on the electrode, resulting decreasing the oxidation current with successive increasing the scan rate and Such type of nature was previously explain for other compound that are similar to isatin or its derivatives ${ }^{37,38}$. Peak current ratio $\mathrm{I}_{\mathrm{pf}} / \mathrm{I}_{\mathrm{pr}}$ are nearly unity that show quasi reversible nature of the system and this ratio moving toward unity on increasing scan rate and after repletion of cycle at different scan rate. We get same result then it can be consider as criteria for the stability of the oxidized or intermediate compound which formed at the surface of electrode under experimental condition ${ }^{39-41}$. With increasing the value of $v$ the experimental peak function $\left(\mathrm{Ip} / \mathrm{Acv}^{1 / 2}\right)$ for this peak decrease significantly thus with $0.01 \mathrm{M}$ of Schiff base and scan rate 30,50 and $75 \mathrm{mV} / \mathrm{s}$ the value of $\mathrm{Ip} / \mathrm{Acv}^{1 / 2}$ are $0.109 \mathrm{~mA}, 0.0345 \mathrm{~mA}$ and $0.0127 \mathrm{~mA}$. This behavior indicate that 1a Schiff base was strongly absorbed at carbon paste electrode ${ }^{37}$.

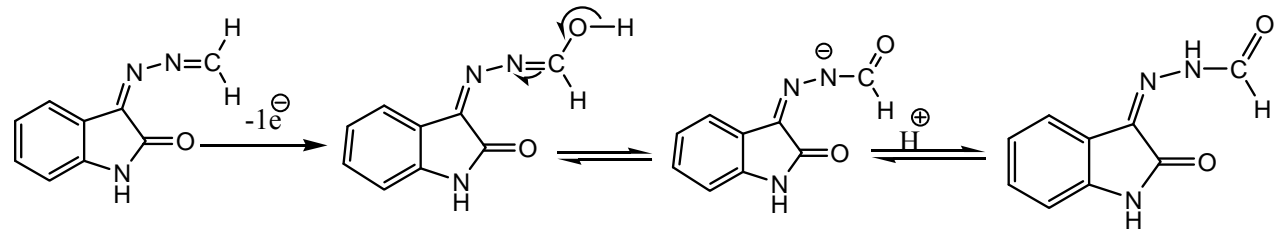

Scheme 2. Proposed oxidation mechanism of isatin -3-(methyenel)-hydrazone in $\mathrm{pH}$ 6.8, 0.2 mphosphate buffer

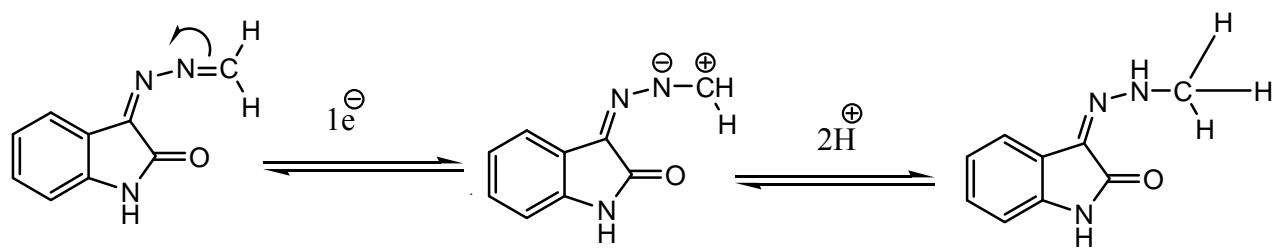

Scheme 3. Proposed reduction mechanism of isatin -3-(methyenel)-hydrazone in $\mathrm{pH} \mathrm{6.8,} 0.2$ mphosphate buffer

\section{Conclusion}

Result of this work show that oxidation of Schiff base at carbon paste electrode is quasi reversible nature but successively increase the scan rate ratio of $\mathrm{I}_{\mathrm{pf}} / \mathrm{I}_{\mathrm{pr}}$ become unity, so it become just like a reversible nature. During the reverse scanning of potential, due to oxidation of Schiff base, aldehydes is formed that strongly adsorbed on the electrode and show good stability because with increasing scan rate current decrease. During the forward scanning of potential $1 \mathrm{e}$ reduction is takes place and result a secondary amine is formed.

\section{Acknowledgement}

The author is very thankful to UGC new Delhi for financial support and Dr. H.S. Singh Gour University, Sagar (M.P.), BHU, department of chemistry for characterization of sample, The valuable helped provided by prof. S.K. Shrivastav (HOD) and providing the necessary facilities including ultra- sonicator.

\section{Reference}

1. Rani P, Srivastava V K and Kumar A, Eur J Med Chem., 2004, 39(5), 449-452; DOI:10.1016/j.ejmech.2003.11.002 
2. Palluotto F, Campagna F, Carotti A, Ferappi M, Rosato A and Vitali C, Farmaco Il, 2002, 57(1), 63-69; DOI:10.1016/S0014-827X(01)01173-9

3. Goyal R.N and Sangal A, J Electroanal Chem., 2005, 578(2), 185-192; DOI:10.1016/j.jelechem.2004.12.034

4. Li P K and Witt-Enderby P A, Drugs Future, 2000, 25(9), 945-957.

5. Suzen S and Buyukbingol E, II Farmaco, 2000, 55(4), 246-248; DOI:10.1016/S0014827X(00)00028-8

6. Avery D, Lenz M and Landis C, Ann Med., 1998, 30(1), 122-130; DOI:10.3109/07853899808999394

7. Chyan Y I, Poeggeler B, Omar R A, Chain D G, Frangione B and Ghisc M A, J Biol Chem., 1999, 274, 21937-21942; DOI:10.1074/jbc.274.31.21937

8. Bast A and Haenen G R, Adv Exp Med Biol., 1990, 264, 111-116.

9. Reiter R J, Neurochem Int., 1995, 27(6), 453-460; DOI:10.1016/01970186(95)80002-3

10. Ischia M, Palumbo A and Prota G, Tetrahedron, 1988, 44(20), 6441-6446; DOI:10.1016/S0040-4020(01)89832-X

11. Glover V, Bhattacharya S K, Chakrabarti A and Sandler M, Stress Med., 1998, 14(4), 225-229.

12. Igosheva N, Lorz C, O'Conner E, Glover V and Mehmet H, Neurochem Int., 2005, 47(3), 216-224; DOI:10.1016/j.neuint.2005.02.011

13. Glover V, Revely M.A, Sandler M., Biochem Pharmacol., 1980, 29(3), 467-470; DOI:10.1016/0006-2952(80)90534-1

14. Silva J F M., Garden S J and Pinto A C, J Braz Chem Soc., 2001, 12(3), 273-324,

15. Shvekhgeimer M G A, Chem Heterocycl Compd., 1996, 32(3), 249-276; DOI:10.1007/BF01169241

16. Shuttleworth S J, Nasturica D, Gervais C, Siddiqui M A, Rando R F and Lee N, Bioorg Med Chem Lett., 2000, 10(22), 2501-2504; DOI:10.1016/S0960894X(00)00523-0

17. Adibi H, Khodaei M M, Pakravan P and Abiri R, Pharm Chem J., 2000, 44(4), 219227; DOI:10.1007/s11094-010-0436-3

18. Sridhar S K, Saravanan M and Ramesh A, Eur J Med Chem., 2001, 36(7-8), 615-625; DOI:10.1016/S0223-5234(01)01255-7

19. Rollas S and Kuçukguzel S G, Molecules, 2007, 12(8), 1910-1939; DOI:10.3390/12081910

20. Farnia G, Capobianco G and Romanin A, J Electroanal Chem., 1973, 45(3), 397404; DOI:10.1016/S0022-0728(73)80049-X

21. Chi Y, Chen H and Chen G, Anal Chim Acta, 1997, 354(1-3), 365-373; DOI:10.1016/S0003-2670(97)00460-1

22. Khattab M A and Ghoneim M M, J Indian Chem Soc., 1983, LX, 643.

23. Agarwal H P and Bhargava M, Ind J Chem., 1974, 12, 84-86.

24. Mamedov V A, Kalinin A A and Yanilkin V V, Russian Chem Bull., 2007, 56(10), 2060-2073; DOI:10.1007/s11172-007-0322-7

25. Xu H, Wang D, Zhang W, Zhu W, Yamamoto K and Jin L, Anal Chim Acta, 2006, 577(2), 207-213; DOI:10.1016/j.aca.2006.06.042

26. Wang M Y, Xu X Y and Gao J, J Appl Electrochem., 2007, 37(6), 705-710; DOI:10.1007/s10800-007-9303-7

27. Barek J, Moreira J C and Zima J, Sensors, 2005, 5(4), 148-158; DOI:10.3390/S5040148 
28. Contabrana B, Baamonde A, Andres-Irellas F and Hidalgo A, Gen Pharm., 1990, 21, 89.

29. Zhang W, Zhao Y and Qigang H, Shengzhi Biyun., 1989, 9, 16.

30. Pandeya S N, Sriram D and Nath G, Eur J Pharm Sci., 1999, 9(1), 25-31; DOI:10.1016/S0928-0987(99)00038-X

31. Cerchiaro G and Ferreira A M, J Braz Chem Soc., 2006, 17(8), 1473-1485.

32. Medvedev A E and Glover V, Biochemistry, 2007, 3, 192

33. Oliveira Brett A M, Diculescu V C and Piedade J A P, Bioelectrochem., 2002, 55(1-2), 61-62; DOI:10.1016/S1567-5394(01)00147-5

34. Oliveira Brett A M, Piedade J A P, da Silva L A and Diculescu V C, Anal Biochem., 2004, 332(2), 321-329; DOI:10.1016/j.ab.2004.06.021

35. Oliveira Brett A M and Matysik F.-M, Bioelectrochem Bioenergy, 1997, 42, 111-116.

36. Goyal R N, Kumar N and Singhal N K, Bioelectrochem Bioenergy, 1998, 45, 47.

37. $\mathrm{Hu} \mathrm{T}$ and Dryhurst $\mathrm{G}, \mathrm{J}$ Electroanal Chem., 1993, 362(1-2), 237-248; DOI:10.1016/0022-0728(93)80026-E

38. $\mathrm{Hu} \mathrm{T}$ and Dryhurst $\mathrm{G}, \quad J$ Electroanal Chem., 1997, 432(1-2), 7-18; DOI:10.1016/S0022-0728(97)00227-1

39. Nematollahi D, Amani A and Tammari E, J Org Chem., 2007, 72, 3646-3651.

40. Hosseiny Davarani S S, Nematollahi D, Mashkouri Najafi N, Masoumi L and Ramyar S, J Org Chem., 2006, 71(5), 2139-2142; DOI:10.1021/jo0523767

41. Nematollahi D and Rafiee M, Green Chem., 2005, 7(9), 638-644. 